\title{
LINGUA-PRAGMATIC CHARACTERISTICS OF BILINGUALISM COVERAGE IN MEDIA DISCOURSE OF TATARSTAN
}

\author{
CARACTERÍSTICAS LINGUA-PRAGMÁTICAS DA COBERTURADO BILINGUALISMO NO \\ DISCURSO MIDIÁTICO DO TARTARISTÃO
}

\author{
CARACTERÍSTICAS LINGUA-PRAGMÁTICAS DE LA COBERTURA DEL BILINGÜISMO \\ EN EL DISCURSO MEDIÁTICO DE TATARSTÁN
}

\author{
Albina Rishatovna MORDVINOVA ${ }^{1}$ \\ Aida Gumerovna SADYKOVA ${ }^{2}$ \\ Nailya Irekovna GOLOLOBOVA ${ }^{3}$
}

\begin{abstract}
The article represents the results of the Tatar media discourse analysis aimed to the defining the lingua-pragmatic characteristics of bilingualism coverage and pragmatic settings of the Tatar linguistic identity as well (in relation to regional and individual bilingualism), as media discourse has "exclusive suitability [...] in researches on bilingual linguistic identity discourse" (ANTONOVNA; RISHATOVNA; GUMEROVNA, 2019). Having analyzed 50 newspaper articles and 16 posts (all found) in social network Vkontakte (vkontakte vk.com). with bilingualism as the central topic, the authors came to the following conclusions about the peculiarities of bilingualism coverage in Tatar media discourse: in traditional media discourse the problem of bilingualism is widely covered, while in Tatar internet discourse it finds rather weak coverage, but much more emotional (as the topic is raised by speakers with strong national identity only). Due to the fact that "Russian is still the prevalent functional language in all spheres of language use in Tatarstan" (VESSEY, 2013). both in traditional media discourse and internet discourse the use of the Tatar language in all spheres of life is understood as bilingualism, not the coexistence of the two official languages of the Republic, though the recognition of bilingualism as the part of national identity also takes place. The actual position of the Tatar language is stated not legitimate and both the government of the Republic and the ordinary native speakers are to be blamed for it. It is frequently mentioned that the development of harmonious bilingualism in Tatarstan requires the adoption of additional legislative measures, strict control over their compliance, wider and better implementation of the Tatar language in the educational and legislative processes, holding events in support of the tatar language, etc. in internet discourse, the problem of bilingualism in family circle is also raised.
\end{abstract}

KEYWORDS: Media discourse. Bilingualism. Linguistic identity. Pragmatic settings. Language policy.

\footnotetext{
${ }^{1}$ Kazan Federal University (KPFU), Kazan - Russia. Assistant Lecturer of the Department for Foreign Languages and Professional Communications, Institute for Management, Economy and Finances. ORCID: https://orcid.org/0000-0002-4720-9042. E-mail: tien92@mail.ru

${ }^{2}$ Kazan Federal University (KPFU), Kazan - Russia. Professor of the Department for Theory and Practice of Foreign Language Teaching, Institute of Philology and Intercultural Communication. ORCID: https://orcid.org/0000-0001-5358-4087. E-mail: a sadykova@bk.ru

${ }^{3}$ Kazan Federal University (KPFU), Kazan - Russia. Senior Lecturer of the Department for Foreign Languages and Professional Communications, Institute for Management, Economy and Finances. ORCID: https://orcid.org/0000-0001-8451-3812. E-mail nailya.gololobova@gmail.com
}

Rev. EntreLínguas, Araraquara, v. 7, n. esp. 1, p. 95-104, fev. 2021. 
RESUMO: O artigo representa os resultados da análise do discurso da mídia tártara que visa definir as características linguísticas pragmáticas da cobertura do bilinguismo e configurações pragmáticas da identidade linguística tártara (em relação ao bilinguismo regional $e$ individual), como o discurso da mídia tem "adequação exclusiva [...] em pesquisas sobre o discurso da identidade linguística bilíngue"(ANTONOVNA; RISHATOVNA; GUMEROVNA, 2019) tendo analisado 50 artigos de jornal e 16 posts (todos encontrados) na rede social vkontakte (vkontakte vk.com). tendo o bilinguismo como o tópico central, os autores chegaram às seguintes conclusões sobre as peculiaridades da cobertura do bilinguismo no discurso da mídia tártaro: no discurso da mídia tradicional, o problema do bilinguismo é amplamente coberto, enquanto no discurso da internet tártaro encontra uma cobertura bastante fraca, mas muito mais emocional (já que o tópico é levantado por palestrantes com forte identidade nacional apenas). devido ao fato de que "o russo ainda é a língua funcional prevalente em todas as esferas de uso da língua no Tartaristão" (VESSEY, 2013). tanto no discurso da mídia tradicional quanto no discurso da internet, o uso da língua tártara em todas as esferas da vida é entendido como bilinguismo, não a coexistência das duas línguas oficiais da república, embora o reconhecimento do bilinguismo como parte da identidade nacional também ocorra. a posição real da língua tártara não é declarada legítima e tanto o governo da república quanto os falantes nativos comuns são culpados por isso. é frequentemente mencionado que o desenvolvimento do bilinguismo harmonioso no Tataristão requer a adoção de medidas legislativas adicionais, controle estrito sobre seu cumprimento, implementação mais ampla e melhor da língua tártara nos processos educacionais e legislativos, realização de eventos em apoio à língua tártara etc. no discurso da internet, o problema do bilinguismo no círculo familiar também é levantado.

PALAVRAS-CHAVE: Discurso de mídia. Bilinguismo. Identidade linguística. Configurações pragmáticas. Política de linguagem

RESUMEN: El artículo representa los resultados del análisis del discurso de los medios tártaros dirigido a definir las características lingua-pragmáticas de la cobertura del bilingüismo y los escenarios pragmáticos de la identidad lingüística tártara también (en relación con el bilingüismo regional e individual), como lo ha hecho el discurso de los medios " idoneidad exclusiva [...] en investigaciones sobre el discurso de la identidad lingüistica bilingüe "(ANTONOVNA; RISHATOVNA; GUMEROVNA, 2019). habiendo analizado 50 artículos periodisticos y 16 publicaciones (todas encontradas) en la red social vkontakte (vkontakte vk.com). con el bilingüismo como tema central, los autores llegaron a las siguientes conclusiones sobre las peculiaridades de la cobertura del bilingüismo en el discurso de los medios tártaros: en el discurso de los medios tradicionales, el problema del bilingüismo está ampliamente cubierto, mientras que en el discurso tártaro de internet encuentra una cobertura bastante débil, pero mucho más emocional (ya que el tema lo plantean oradores con una fuerte identidad nacional únicamente). debido al hecho de que "el ruso sigue siendo el idioma funcional predominante en todas las esferas del uso del lenguaje en tartaristán” (VESSEY, 2013). tanto en el discurso mediático tradicional como en el discurso de internet el uso de la lengua tártara en todos los ámbitos de la vida se entiende como bilingüismo, no como coexistencia de las dos lenguas oficiales de la república, aunque también se da el reconocimiento del bilingüismo como parte de la identidad nacional. se afirma que la posición real del idioma tártaro no es legítima y tanto el gobierno de la república como los hablantes nativos ordinarios son culpables de ello. con frecuencia se menciona que el desarrollo del bilingüismo armonioso en tartaristán requiere la adopción de medidas legislativas adicionales, un control estricto de su cumplimiento, una implementación más amplia y mejor del idioma 
tártaro en los procesos educativos y legislativos, la realización de eventos en apoyo del idioma tártaro. etc. en el discurso de internet también se plantea el problema del bilingüismo en el círculo familiar.

PALABRAS CLAVE: Discurso mediático. Bilinguismo. Identidad linguística. Entornos pragmáticos. Política lingüistica

\section{Introduction}

Media discourse "is a powerful means of producing and reproducing ideological discourses about language and nation" (WIGGLESWORTH-BAKER, 2016). At the moment, the linguo-pragmatic image of bilingualism (in particular, Tatar-Russian one) in the Tatar media discourse of the Republic of Tatarstan is not studied properly yet. We can note the paper of A. N. Nurutdinova "Discourse of multilingualism in the press and Internet resources of Tatarstan (НУРУТДИНОВА, 2018). where the author identifies the key characteristic of the media discourse of the Republic of Tatarstan in terms of "rhetoric of multilingualism": "actualization of the position of the Republic of Tatarstan as a multi-ethnic region where different peoples historically live and exchange experience". However, this paper did not focus directly on the constitutionally established bilingualism of the Republic (the official languages are Russian and Tatar).

\section{Methods}

To clarify the attitude of the Tatar linguistic personality to the phenomenon of bilingualism (regional, individual, institutional, etc.) in the Tatar media discourse, we analyzed 50 articles from various Tatar newspapers and magazines, including online ones, covering various aspects of bilingualism (the search was made on the basis of the written corpus of the modern Tatar language (https://www.corpus.tatar) published from 2010 to 2019 inclusively. The question of identifying units of discourse analysis is currently open, and in this study, we consider the unit of discourse analysis to be a part of the article - a sentence, a paragraph, in some cases an entire article that covers one aspect of bilingualism (an event related to bilingualism, implementation of bilingualism in some sphere of public life, etc.) or an expression of attitudes to bilingualism as a whole or to one of the aspects of its implementation. A total of 91 cases of coverage of various aspects of bilingualism were recorded. The classification given below is quite relative: it was found that in the Tatar media discourse, in most cases, bilingualism in the Republic of Tatarstan is equated to the language proficiency in 
Tatar and its use in various spheres of public life, and not directly to bilingualism; and, since we are interested in the image of bilingualism itself as the coexistence of two languages in one community, the statistics are summed up taking into account the analysis of the verbal content of paragraphs and sentences containing the words “икетеллелек”, “билингвизм” bilingualism, “дәүләт телләр" official languages.

However, let us note that journalists and interviewees in national press usually have strong national identity and drawing conclusions about pragmatic settings of the Tatar bilingual linguistic identitty as a whole could be wrong. For greater objectivity, there was search for “икетеллелек”, «билингвизм» bilingualism made in the social network Vkontakte; undoubtedly, this issue will be raised mainly by ideologically minded people in internet discourse as well, however, less control over the content of social networks may make it possible to see other aspects of coverage of the phenomenon of bilingualism in the Republic of Tatarstan in the Tatar media discourse.

\section{Results and discussion}

Let us take a closer look at each category and the pragmatic settings of the Tatar bilingual linguistic identity behind them.

1) Contrasting the official bilingualism of the Republic of Tatarstan with the actual linguistic situation (26 in total).

The discrepancy between the legally established bilingualism of the Republic of Tatarstan and the actual linguistic situation (15) is one of the most acute issues raised in the Tatar press of Tatarstan: «Татарстанда ... икетеллелек кәгазьдә генә саклана дияргә була» (БЕЗНЕН ГӘЖИТ https://beznen.ru) in Tatarstan ... bilingualism is maintained only on paper etc. Different authors of different publications raise the following subtopics: 1) failed attempts to rectify the situation (6): «Күпме генә тырышсак та, татар теле республикада рус теле белән тигез дәрәжәдәге дәүләт теленә әверелмәде» (МӘДӘНИ ЖОМГА https://madanizhomga.ru) No matter how much we tried, the Tatar language in the Republic did not become an equal official language along with the Russian language etc., 2) search for the guilty and admitting guilt in this situation (5) - «Икетеллелекнең гамәлдә булмавында кем гаепле?» Who is to blame for the fact that bilingualism does not function? (МӘЙДАН http://maydan.tatar). «Без үзебезнең кулдан килердәй гап-гади нәрсәләрне дә эшләмибез 
бит» We do not do everything that we can do etc., emotional perception of the problem is expressed - “Эх, егетләр, саттык бит без телебезне!” Oh, guys, we sold our language! etc.

2) Implementation of bilingualism in education - 16 .

When covering bilingualism in the Republic of Tatarstan in the educational aspect, the following sub-topics are observed: 1) actual discrepancy of the language balance in the Republic of Tatarstan in the field of education (6) - «икетелле мәктәп мәгарифе моделен үстерергә кирәк» it is necessary to develop a model of bilingual school education (Матбугат https://matbugat.ru) etc.; 2) measures taken in this regard (5) - «2014-2020 елларга Татарстан Республикасында Татарстан Республикасындагы дәүләт телләрен һәм башка телләрне саклау, өйрәнү һәм үстерү” дигән дәүләт программасы нигезендә мәгариф бүлеге үз программасын кабул итте» (КАЙБЫЧ ТАННАРЫ http://kaibicy.ru) the Department of education has adopted its program in accordance with the state program "preservation, study and development of official languages of the Republic of Tatarstan and other languages in the Republic of Tatarstan for 2014-2020; 4) the positive impact of bilingualism on the younger generation (3) - «Безнең ике тел белүче балалар яхшырак сөйли һәм яза» Our bilingual children speak and write better, (КАЙБЫЧ ТАННАРЫ http://kaibicy.ru). etc.; 4) the low status of the Tatar language as a discipline (2) «Кайберләре икетеллелек мәжбүр булган өчен генә укый» Some [pupils] are forced to learn [Tatar] only because bilingualism is mandatory (ТАТАР-ИНФОРМ https://www.tatar-inform.ru) etc.;

3) the legal and historical aspect of the development of bilingualism in RT - 12 3 subcategories are defined: 1) various aspects of the implementation of language legislation in the Republic of Tatarstan (7 in total) - «2007 елда районда республикадагы икетеллелек закон проекты буенча комиссия төзелде» in 2007, the district established a Commission on Republican bill on bilingualism (ӘЛМӘТ ТАННАРЫ httр://almet-rt.ru ).etc.; 2) a different aspect of the failure of language legislation in the Republic of Tatarstan (4) «Элмә такталар Татарстанның ике дәүләт телендә - татар һәм рус телләрендә куелмый икән, дәүләт хакимияте оешмаларының, жирле үзидарә оешмаларының, ширкәтләрнең һәм башка оешмаларның вазифадагы кешеләренә 500 сумнан 1000 сумга кадәр штраф салыначак» If the signs are not installed in the two official languages of Tatarstan-Tatar and Russian, then officials of state authorities, local governments, firms and other organizations will be fined from 500 to 1000 rubles (ШӘһРИ ЧАЛЛЫ http://shahrichalli.ru) etc.; 3) initiative concerning the language legislation of the Republic of Tatarstan (1) - «Ул Татарстанда татар 
теленең кулланылышын, икетеллелекне контрольдә тоту буенча дәүләт органын, бу юнәлештә эшләүче омбудсмен вазифасын булдыру тәкъдиме белән чыкты» he proposed to create a state body in Tatarstan to monitor the use of the Tatar language and bilingualism and to establish an Ombudsman working in this direction (ТАТАР-ИНФОРМ https://www.tatar-inform.ru)

4) Necessity, importance and inevitability of bilingualism as a global trend - 11 «Ике телне белсәң, эш, үсеш перспективасы булырга тиеш» If you know two languages, there must be a job and growth prospects (ТАТАР-ИНФОРМ https://www.tatarinform.ru) was also expressed in the following characteristics of bilingualism given in various publications RT: «заман таләбе» demand of our time (КЫЗЫЛ ТАН https://kiziltan.rbsmi.ru), «иң беренче таләпләрнең берсе» the first of all demands, (Сарман http://sarman-rt.ru). «дөньякүләм тренд» global trend, (ШӘһРИ КАЗАН http://shahrikazan.ru). «XXI гасырның иң алдынгы күрсәткечләрнең берсе» one of the main indicators of the 21st century (BATAНЫM ТАТАРСТАН https://vatantat.ru). etc.

5) News coverage of events related to the implementation of bilingualism in RT 9.

Emotionally neutral, it concerned the usage of the Tatar language in transport and public places, holding events in defense of the Tatar language (which confirms that bilingualism in the Tatar press is equated with the use of the Tatar language), studying the experience of bilingualism in other countries: «22 апрельдә “Мин татарча сөйләшәм!” акциясе кысаларында тугызынчы “Татар-дозор 2017” квест-уены уздырала» On April 22 the gamequest "Tatar-Dozor 2017" will be held for the ninth time as part of "I speak Tatar" campaign (ТАТАР-ИНФОРМ https://www.tatar-inform.ru )etc.

6) Preservation and development of bilingualism in RT -7.

As already mentioned, examples from this category include directly those cases where the preservation and development of bilingualism as a goal are expressed explicitly: «Кайбыч таңнары» газетасы редакциясе Татарстанда икетеллелекне саклау һәм үстерүгә үзеннән лаеклы өлеш кертә» The editorial office of the newspaper "Kaibitski Dawns" makes a worthy contribution to the preservation and development of bilingualism in Tatarstan (КАЙБЫЧ ТАННАРЫ http://kaibicy.ru)etc. 
7) Positive aspects of bilingualism (5)

Bilingualism as a positive phenomenon is characterized by the lexemes "байлык" wealth (ТАТАР-ИНФОРМ https://www.tatar-inform.ru, Идел http://idel-tat.ru), “файда” benefit, (ТАТАР-ИНФОРМ https://www.tatar-inform.ru). etc.

8) Bilingualism as part of the cultural identity of the RT residents (3)

Journalists and interviewees emphasize the importance of bilingualism for RT: «безнең үзенчәлек» our feature, (BATAНЫМ ТАТАРСТАН https://vatantat.ru). «уңышыбыз hәм көчебез» our success and our strength, (АЛАБУГА НУРЫ http://alabuganury.ru) etc.

9) Bilingualism in cultural life of the Republic (1)

“шагыйрә Венера Думаева-Вәлиева күбрәк биллингва-китаплар нәшер итүгә житди игътибар бирергә киңәш итә» poet Venera Dumayeva-Valieva, who has devoted her life to translating Tukai into Russian, advises paying more attention to the publication of bilingual books (КАЗАН УТЛАРЫ http://kazanutlary.ru). etc.

What concerns the search results in social network Vkontakte, (VKONTAKTE vk.com ).we analyzed the posts of the head of the Zelenodolsk Tukai Foundation, Klara Filippova, the Chairman of the world forum of Tatar youth, Tabris Yarullin, and other users, including participants of online marathons held under the hashtags \#әдәбимарафон \#татнетныүстерүфонды \#татарстанкитапнәшрияты100ел and \#әниләрмарафоны (16 posts in total - we did not count the posts of articles in the accounts of registered mass media, which made up the majority of the results, and their reposts). In all the analyzed posts, the issue of bilingualism was raised indirectly within the framework of protecting the Tatar language.

1) Non-compliance with the bilingualism language policy -8 :

«Татарстанда парламент һәм хөкүмәтнең бер генә утырышы да татар дәүләт телендә үткәрелмәде» not a single session of the Parliament and government in Tatarstan was held in the Tatar language that is an official one, etc., including non - compliance with bilingualism in the field of education (1) - «имтиханнарын бары тик рус телендә генə биру мәжбүриятен керттеләр» exams were required to pass only in Russian.

2) Activities of public organizations carried out in defense of bilingualism - 6: «Барыгызны да “Мин татарча сөйләшәм!” дә көтеп калабыз» we are waiting for everyone at the "I speak Tatar!" etc. 
3) Criticism of the authorities in terms of measures taken to comply with official bilingualism -6 :

«житәкчеләр әле бүген дә икетеллелекне урысча кабул ителгән законнарны татарчага аудару дип кенә аңлый кебек» the leaders still understand bilingualism only as a translation of laws adopted in Russian into Tatar, etc. In three posts, the word «икейөзлелек» duplicity is used to characterize the official bilingualism in Tatarstan.

4) Use of the Tatar language in the family circle - 4:

«өйдә русча сөйләшү тыелган. Урам, мәткәп өйрәтте балаларны русчага. Каршы түгелмен, әлбәттә)» at home, it is forbidden to speak Russian. The street and school taught children Russian. Not against, of course), etc. Participants of the \#әниләрмарафоны mothersmaraphon unanimously expressed their desire to use exclusively Tatar language in the family circle, since children communicate in Russian in kindergarten, school and playing outside.

5) Recognition of certain achievements of language policy -2 :

«бөтен жирдә татарча язмалар, эленмәләр эленеп тора» everywhere there are inscriptions and signs in the Tatar language, etc.

6) Admission of guilt - 1:

«беришләребез ана телен корбан итәргә дә әзер булып чыга» some of us are willing to sacrifice our native language.

7) Action requirement - 1:

«Татар теле тулы хокуклы тел сыйфатында тормышның бөтен өлкәләрендә дә файдаланылырга тиеш» The Tatar language should be used in all spheres of life as a fullfledged language.

8) Bilingualism is obligatory -1 :

«Күпмилләтле халыклы республикада яшәгәч чи татар телен генә белүне таләп итеп куеп булмасымны аңлыйм» Living in a multi-ethnic Republic, I understand that it is impossible to require knowledge of the Tatar language only.

9) Bilingualism is a trend -1 :

«Соңгы вакытта телләр өйрәнү модага кереп бара» Recently, language learning has become fashionable. 
Let us singly comment on the post - the poem of the Tatar poet Saniya Akhmetzyanova “Икетеллелек" bilingualism. On the one hand, Russian and Tatar languages in the RT are represented as equal parts of the RT residents national identity (1): «həр икесен тигез дибез, бердәй хаклы ... Икесе дә дәүләт теле, халык яклы...» we say that both are equal and have equal rights... both are official languages, both are national ones..." on the other hand, the author urges Tatars to use their native language more, even to the point of abandoning the Russian language (1) «Ике телнең берсен кисеп, сакау булмыйк» If we cut one of the two tongues off, we will not remain Burr-like.

\section{Summary}

The coverage of the bilingualism problem in the RT in the internet discourse is more emotional and criticizing than in traditional media discourse, main topics covered are noncompliance with the language legislation of the RT, explicit accusations of government, using the Tatar language in the family circle, the motive for refusing to use the Russian language (at least in the family circle).

\section{Conclusions}

Let us sum it all up: in the traditional Tatar media discourse the issue of bilingualism in the Republic of Tatarstan is widely covered, mostly emphasizes the discrepancy between legally established and actual condition of bilingualism in The Republic and the adoption of measures to improve this situation, aimed at the wider use of the Tatar language in educational process, expansion of its functions as language of institutional communication, promotion of the language among the population, particularly among young people, etc. In the Tatar internet discourse, the problem of bilingualism in the Republic of Tatarstan finds rather weak coverage, but it is much more emotional. Based on the analysis of Tatar media discourse, the following conclusions can be drawn about the image of bilingualism in pragmatic settings of Tatar bilingual linguistic personality with a high degree of national consciousness:

- bilingualism is equivalent to the use of the Tatar language in all spheres of life,

- the actual position of the Tatar language is invalid and not legitimate, and both the government of RT and the ordinary native speakers are to be blamed for it;

- the development of harmonious bilingualism in the Republic requires the adoption of additional legislative measures, strict control over their compliance, wider and better 
implementation of the Tatar language in the educational and legislative processes, holding events in support of the Tatar language, etc.

- poor coverage of bilingualism problems in Tatar internet discourse (consider the fact that active social media users are mostly younger generation) confirms the fact that not all Tatars are concerned about the non-compliance of the language legislation in the Republic of Tatarstan, and for less ideologically-minded Tatar speakers respect of bilingualism in the Republic is not a significant value.

ACKNOWLEDGEMENTS: The work is performed according to the Russian Government Program of Competitive Growth of Kazan Federal University.

\section{REFERENCES}

ANTONOVNA, T. E.; RISHATOVNA, M. A.; GUMEROVNA, S. A. Media discourse as research material for bilingual linguistic identity studies. Revista Inclusiones. v. 6, p. 752$758,2019$.

VESSEY, R. Language ideologies and discourses of national identity in Canadian newspapers: a cross-linguistic corpus-assisted study. Queen Mary: University of London, 2013.

WIGGLESWORTH-BAKER, T. Language policy and post-Soviet identities in Tatarstan. Nationalities Papers, v. 44, n. 1, p. 20-37, 2016.

НУРУТДИНОВА, А. Н. Дискурс многоязычия в прессе и Интернет-ресурсах Татарстана. Вестник экономики, права и социологии, n. 2, 2018.

\section{How to reference this article}

MORDVINOVA, A. R.; SADYKOVA, A. G.; GOLOLOBOVA, N. I. Lingua-pragmatic characteristics of bilingualism coverage in media discourse of Tatarstan. Rev. EntreLínguas, Araraquara, v. 7, n. esp. 1, p. 95-104, fev. 2021. e-ISSN: 2447-3529. DOI: https://doi.org/10.29051/el.v7iEsp1.14876

Submitted: $28 / 10 / 2020$

Required revisions: $19 / 12 / 2020$

Approved: $13 / 01 / 2021$

Published: 28/02/2021 